\title{
Age is not a determinant factor in susceptibility of broilers to H5N2 clade 2.3.4.4 high pathogenicity avian influenza virus
}

\author{
Kateri Bertran, Dong-Hun Lee, Charles Balzli, Mary J. Pantin-Jackwood, Erica Spackman and David E. Swayne*
}

\begin{abstract}
In 2014-2015, the US experienced an unprecedented outbreak of H5 clade 2.3.4.4 highly pathogenic avian influenza (HPAl) virus. The H5N2 HPAl virus outbreak in the Midwest in 2015 affected commercial turkey and layer farms, but not broiler farms. To assess any potential genetic resistance of broilers and/or age-related effects, we investigated the pathogenesis and transmission of A/turkey/Minnesota/12582/2015 (H5N2) (Tk/MN/15) virus in commercial 5-weekold broilers, 8-week-old broilers, and >30-week-old broiler breeders. The mean bird lethal dose $\left(B_{L} D_{50}\right)$ was $5.0 \log _{10}$ mean egg infectious dose $\left(\mathrm{EID}_{50}\right)$ for all age groups. The mean death time (MDT) was statistically not different among the three age groups, ranging between 3.2 and 4.8 days. All broilers that became infected shed high levels of virus with transmission to contacts and demonstrated severe pathology. Mortality and virus shedding results indicated that age is not a determinant factor in susceptibility of broilers to H5N2 clade 2.3.4.4 HPAl virus. Previously, the TK/ MN/15 virus had a BLD 50 of $3.6 \log _{10} E \mathrm{ID}_{50}$ and MDT of 2 days in White Leghorn chickens and a BLD 50 of $5.0 \log _{10} \mathrm{EID}_{50}$ and MDT of 5.9 days in turkeys, suggesting that the broiler breed is less susceptible to Midwestern H5N2 virus than the layer breed but similarly susceptible to turkeys. Therefore, genetic resistance of broilers to infection may have accounted only partially for the lack of affected broiler farms in the Midwestern outbreaks, with other contributing factors such as fewer outside to on farm exposure to contacts, type of production management system or enhanced biosecurity.
\end{abstract}

\section{Introduction}

The Asian-origin H5N1 A/goose/Guangdong/1/1996 (Gs/GD) lineage of high pathogenicity avian influenza (HPAI) virus has become widespread across several continents, affecting wild birds, poultry, and humans. In late 2014, Eurasian H5N8 and reassortants H5N2 and H5N1 Gs/GD lineage clade 2.3.4.4 HPAI viruses were reported in North America [1]. The initial incursion of this viral lineage into the US was detected in December 2014 in Washington state in a wild Northern pintail duck (Anas acuta) [2]. The $\mathrm{H} 5 \mathrm{~N} 2$ virus was a reassortant containing five Eurasian avian influenza (AI) virus gene segments [including the H5 2.3.4.4 hemagglutinin (HA)] and three

\footnotetext{
*Correspondence: david.swayne@ars.usda.gov

Exotic and Emerging Avian Viral Diseases Research Unit, Southeast Poultry Research Laboratory, US National Poultry Research Center, Agricultural Research Service, US Department of Agriculture, 934 College Station Rd, Athens, GA 30605, USA
}

North American wild bird lineage low pathogenic (LP) AI virus gene segments [2-4]. Over the next 7 months, the US experienced the worst HPAI event for US poultry producers: more than 7.5 million turkeys and 42.1 million chickens died or were culled during the control program [5] and imports of US poultry and poultry products from many different countries were banned [6].

While the majority of initial H5 HPAI viruses were detected in wild waterfowl, wild and captive birds of prey, and backyard flocks along the Pacific flyway [5, 7], most cases in the Midwest in 2015 affected commercial turkey and chicken layer premises [5]. Experimentally, H5N2 HPAI viruses isolated from the Midwestern poultry cases in 2015 were generally better adapted to White Leghorn chickens [8] and turkeys [9], as opposed to the index virus A/Northern pintail/Washington/40964/2014 (H5N2) which was more waterfowl adapted [10, 11] (adaptation meaning efficiency of replication and release 
of the virus from a specific host species, also associated to transmissibility [12]). Overall, the H5N2 virus likely adapted to chicken layers and turkeys during the early Midwestern outbreaks increasing infectivity and transmission, and facilitating spread [10]. Other epidemiological factors such as weather, husbandry conditions, flock density and composition, but especially breakdowns in farm biosecurity, may have also contributed to the increasing virulence and transmission in the Midwestern commercial farms.

Albeit HPAI viruses produce high morbidity and mortality in gallinaceous domestic poultry regardless of age [13-15], age-related susceptibility, in particular the severity of the clinical signs and the capacity of recovery, has been reported in turkeys and ostriches infected with LPAI viruses [16, 17]. In a natural outbreak of H5N1 influenza virus in commercial ducks in South Korea, 14-day-old meat ducks experienced increased morbidity and up to $12 \%$ mortality rate, with systemic microscopic lesions. In contrast, adult ducks at the affected breeder duck farms showed decreased egg production and feed consumption, but no mortality [18]. Experimentally, an effect of virus strain and host age on the resulting pathogenicity was observed in 2- and 5-week-old Pekin ducks infected with different Asian-origin HPAI H5N1 viruses [19]. Reproductively active adult Japanese quail (Coturnix c. japonica) had stronger immune responses than pubescent and aged birds, suggesting an age-related difference in immune function [20].

The different genetic background between layer-type and broiler-type chickens may have an effect not only on performance but also on genetic expression and immunological responses [21-23]. Differences in susceptibility between layers and broilers have been reported for AI virus infection [24-31]. Experimentally, the intravenous inoculation of high dose of A/chicken/Alabama/7395/75 (H4N8) caused more severe renal disease in White Leghorns than in broilers [24]. In another study, broiler breeds were identified as generally more resistant to A/ chicken/Italy/13474/99 (H7N1) HPAI virus than layer breeds [29]. In an experimental study with low dose intranasal challenge with a reverse-genetics-derived rg-A/chicken/Indonesia/7/2003 (H5N1) HPAI virus, there were differences in mean death time (MDT) and mortality rates in congenic White Leghorn chickens, but these differences were mildly influenced by the major histocompatibility complex (MHC) gene and more so by non-MHC background genes [30]. Overall, these data suggest that variations in response to AI virus infection among breeds may be due to genetic-based natural resistance [25, 27-29].

During the outbreaks in the Midwest in 2015, turkey and layer-type chicken farms were affected but broiler farms were not [5], despite close proximity of the three types of production systems [32]. The absence of affected broiler farms could be the result of genetic resistance to infection and/or failure to introduce HPAI virus onto the farms, due to either lack of exposure or good biosecurity. Knowing species-, breed-, and age-related differences in susceptibility could decisively impact optimal management of outbreak control strategies. In the present study, pathogenesis and transmission dynamics of Midwestern H5N2 clade 2.3.4.4 HPAI virus were investigated in commercial broilers of three different ages in order to test the ability of the virus to produce infection in broilers, as opposed to layers, and assess age-related differences in susceptibility.

\section{Materials and methods \\ Virus}

The influenza A isolate A/turkey/Minnesota/12582/2015 (H5N2) (Tk/MN/15) was used as challenge virus. The virus was isolated from a turkey farm in Minnesota from a sample collected April $18^{\text {th }} 2015$. The virus was propagated and titrated by allantoic sac inoculation of 9-10 day-old embryonating chicken eggs (ECE) by standard methods [33].

\section{Phylogenetic analysis}

The Tk/MN/15 virus was selected because it is representative of the Midwest H5N2 cluster both phenotypically [8] and by phylogenetic analysis. For the phylogenetic analysis, a total of $82 \mathrm{HA}$ gene segments were used in this study. Specifically, the nucleotide sequences of 81 H5 HPAI viruses identified from December 2014 to June 2015 in the US were analyzed together with the HA segment of Korean H5N8 virus identified in January 2014 that were available in the GenBank. The nucleotide sequences of HA segment were aligned using MUSCLE [34]. The Bayesian relaxed clock phylogenetic analyses were done using BEAST v1.8.2 [35]. We applied an uncorrelated lognormal distribution relaxed clock method, the Hasegawa-Kishino-Yano nucleotide substitution model and the Bayesian skyline coalescent prior. A Markov Chain Monte Carlo method to sample trees and evolutionary parameters was run for $5.0 \times 10^{7}$ generations. At least three independent chains were combined to ensure adequate sampling of the posterior distribution of trees. BEAST output was analyzed with TRACER v1.4 with $10 \%$ burn-in. The FigTree v.1.4.2 program was used to construct and visualize the maximum clade credibility tree.

\section{Animals and housing}

Crossed-line WPR $\times$ Cornish broiler birds from a commercial producer in GA, USA (an AI-free state during 
the outbreak) were utilized. The birds had been reared under field management conditions, including a typical US vaccination program which comprised a broad range of vaccines, but not exposed to or vaccinated against AI virus. One week prior to challenge, birds were moved from the field to the controlled environment in SEPRL ABSL-3 facilities to maintain biosafety and biosecurity barriers for H5N2 HPAI virus challenge. Birds were obtained at three different ages: 5 -week-old $(5 \mathrm{w})$ broilers as early processing age, 8 -week-old $(8 \mathrm{w})$ broilers as late processing age, and $>30$-week-old broiler breeders $(>30 w)$. Broiler breeders were in lay; all eggs produced during the study were discarded. Prior to inoculation, $30 \%$ of chickens of each age group were ensured to be serologically negative for AI virus infection as determined by hemagglutinin inhibition (HI) test. Also, oral swabs were collected before challenge to confirm absence of virus shedding as determined by quantitative real-time RT-PCR (qRRT-PCR). Each experimental group was housed separately in negative pressure isolators with HEPA-filtered ventilation within the animal biosafety level 3 enhanced facilities at Southeast Poultry Research Laboratory. The birds had ad libitum access to feed and water.

\section{Experimental design and sampling Infectivity and transmission}

To evaluate the mean bird infectious $\left(\mathrm{BID}_{50}\right)$ and lethal $\left(\mathrm{BLD}_{50}\right)$ doses at different ages, each age group was divided into three groups $(n=5 /$ group $)$, each inoculated intranasally with 2 (low dose), 4 (medium dose), or 6 (high dose) $\log _{10}$ mean egg infectious dose $\left(\mathrm{EID}_{50}\right) / 0.1 \mathrm{~mL}$ of $\mathrm{Tk} / \mathrm{MN} / 15$ virus (Table 1$)$. Sham challenged birds of each age were inoculated intranasally with $0.1 \mathrm{~mL}$ of sterile allantoic fluid diluted 1:300 in brain heart infusion (BHI) media (Becton, Dickinson and Company, Sparks, MD, USA). The inoculum titers were subsequently verified by back titration in ECE as 1.9-2.1 (low dose), 3.9-4.5 (medium dose), and 5.7-6.3 (high dose) $\log _{10} \mathrm{EID}_{50} / 0.1 \mathrm{~mL}$. To evaluate the transmissibility of each isolate, three non-inoculated hatch-mates were added to each dose group at 1 day post-challenge $(\mathrm{dpc})$. Clinical signs were monitored daily. Oral swabs were collected from all birds on 2 and $4 \mathrm{dpc}$, placed in $1.5 \mathrm{~mL}$ of BHI with penicillin (2000 units $/ \mathrm{mL}$; Sigma Aldrich), gentamicin $(200 \mu \mathrm{g} / \mathrm{mL}$; Sigma Aldrich) and amphotericin B $(5 \mu \mathrm{g} / \mathrm{mL}$; Sigma Aldrich), and stored at $-80{ }^{\circ} \mathrm{C}$ until use. Severely sick birds were euthanized and counted as dead for the next day in MDT calculations. At $14 \mathrm{dpc}$, surviving birds were bled to evaluate antibody titers and euthanized by intravenous administration of sodium pentobarbital (100 mg/kg body weight).

\section{Pathogenesis}

For each age group, two additional birds were challenged with the high dose $\left(5.7-6.3 \log _{10} \mathrm{EID}_{50} / 0.1 \mathrm{~mL}\right)$ of $\mathrm{Tk} /$ $\mathrm{MN} / 15$ virus to harvest tissue. Upon death, the birds were necropsied and portions of nasal cavity, brain, thymus, trachea, lung, proventriculum, duodenum, pancreas, jejunum-ileum, spleen, kidney, adrenal and gonad, liver, skeletal muscle, comb, and heart were collected in $10 \%$ buffered formalin (Thermo Fisher Scientific, Waltham, MA, USA) for histopathologic evaluation and for detection of AI virus in tissues by immunohistochemistry. Brain, spleen, heart, and lung were also collected in BHI with antibiotics to a $1 \%(\mathrm{wt} / \mathrm{vol}$ ) concentration for viral RNA quantification by qRRT-PCR.

\section{Viral RNA quantification in swabs and tissues}

Swabs and tissues in BHI were processed for qRRT-PCR to determine viral RNA titers. Viral RNA was extracted using MagMAX ${ }^{\mathrm{TM}}-96 \mathrm{AI} / \mathrm{ND}$ Viral RNA Isolation $\mathrm{Kit}^{\circledR}$ (Ambion, Inc.) following the manufacturer's instructions. In tissue homogenates, and in order to standardize the amount of nonspecific RNA from the tissue, the resulting viral RNA extracts were quantified by NanoDrop ${ }^{\mathrm{TM}} 1000$ Spectrophotometer (Thermo Fisher Scientific) following the manufacturer's instructions and accordingly diluted with phosphate buffered saline to obtain $50 \mathrm{ng} / \mu \mathrm{L}$. The resulting viral RNA extracts, diluted (tissue homogenates) or undiluted (swabs), were quantified by one-step qRRT-PCR which targets the influenza matrix gene [36] using 7500 FAST Real-time PCR System (Applied Biosystems, Foster City, CA, USA). The standard curves for viral RNA quantification were established with RNA extracted from dilutions of the same titrated stocks of the challenge viruses. The limit of detection for $\mathrm{Tk} / \mathrm{MN} / 15$ virus was $2.0 \log _{10} \mathrm{EID}_{50} / \mathrm{mL}\left(3.0 \log _{10} \mathrm{EID}_{50} / \mathrm{g}\right.$ for tissue homogenates); for statistical purposes, qRRT-PCR negative samples were given a numeric value of $1.9 \log _{10}$ $\mathrm{EID}_{50} / \mathrm{mL}\left(2.9 \log _{10} \mathrm{EID}_{50} / \mathrm{g}\right)$.

\section{Statistical analysis}

The D'Agostino and Pearson test was used to assess the normality of distribution of investigated parameters. All parameters in our study were not normally distributed. Significant difference for mean viral titers in tissues between groups was analyzed using Kruskal-Wallis test or Mann-Whitney test (GraphPad Prism ${ }^{\mathrm{TM}}$ Version 5 software). A $p$ value of $<0.05$ was considered to be significant.

\section{Histopathology and immunohistochemistry}

Tissues in 10\% formalin were processed for routine hematoxylin/eosin staining. Tissues were also processed for immunohistochemical staining using a mouse-derived 
Table 1 Transmission study design with mortality results and mean bird infectious and lethal doses

\begin{tabular}{|c|c|c|c|c|}
\hline \multirow[t]{2}{*}{ Bird type (age) } & \multirow[t]{2}{*}{ Dose $\left(\log _{10}\right.$ EID $\left._{50}\right)$} & \multicolumn{2}{|c|}{$\begin{array}{l}\text { Mortality (MDT expressed as dpc } \\
\text { or dpe) }\end{array}$} & \multirow[t]{2}{*}{$\mathrm{BID}_{50}$ and $B L D_{50}\left(\log _{10}\right)$} \\
\hline & & Inoculated & Contact & \\
\hline \multirow[t]{3}{*}{ Broilers (5w) } & 2 & $0 / 5$ & $0 / 3$ & 5.0 \\
\hline & 4 & $0 / 5$ & $0 / 3$ & \\
\hline & 6 & $5 / 5(4.8)$ & $3 / 3(5.3)$ & \\
\hline \multirow[t]{3}{*}{ Broilers (8w) } & 2 & $0 / 5$ & $0 / 3$ & 5.0 \\
\hline & 4 & $0 / 5$ & $0 / 3$ & \\
\hline & 6 & $5 / 5(3.2)$ & $3 / 3(4.3)$ & \\
\hline \multirow[t]{4}{*}{ Broiler breeders (>30w) } & 2 & $0 / 5$ & $0 / 3$ & 5.0 \\
\hline & 4 & $0 / 5$ & $0 / 3$ & \\
\hline & 6 & $5 / 5(3.2)$ & $3 / 3(5.7)$ & \\
\hline & Sham inoculated & $0 / 2$ & $0 / 2$ & na \\
\hline \multirow[t]{3}{*}{ SPF White Leghorns $(4 w)^{b}$} & 2 & $0 / 5$ & $0 / 3$ & 3.6 \\
\hline & 4 & $3 / 5(2.3)$ & $0 / 3$ & \\
\hline & 6 & $8 / 8(2)$ & $2 / 2(4)$ & \\
\hline \multirow[t]{3}{*}{ Commercial broad breasted white turkeys $(4 \mathrm{w})^{c}$} & 2 & $0 / 5$ & $0 / 3$ & 5.0 \\
\hline & 4 & $0 / 5$ & $0 / 3$ & \\
\hline & 6 & $21 / 21(5.9)$ & $3 / 3(8)$ & \\
\hline \multirow{2}{*}{\multicolumn{5}{|c|}{$\begin{array}{l}\text { 5w: } 5 \text {-week old broilers, } 8 \text { w: } 8 \text {-week old broilers, }>30 \text { w: }>30 \text {-week-old broiler breeders, } \text { BID }_{50}: \text { mean bird infectious dose, BLD }{ }_{50}: \text { mean bird lethal dose, dpc: days post- } \\
\text { challenge, dpe: days post-exposure, EID } D_{50}: \text { mean egg infectious dose, MDT: mean death time, na: not applicable. } \\
\text { a \#dead birds } \times \text { dpc/total dead birds. }\end{array}$}} \\
\hline & & & & \\
\hline \multicolumn{5}{|c|}{ b For comparative purposes, data from DeJesus et al. [8] on 4-week old SPF White Leghorn chickens challenged with Tk/MN/15 virus have been added. } \\
\hline
\end{tabular}

monoclonal antibody (P13C11, developed at SEPRL) specific for type A influenza virus nucleoprotein, as previously described [10,37].

\section{Serology}

Sera samples were tested by HI assays against the challenge antigen. The antigen was prepared as previously described [38] and the HI assays were performed according to standard procedures [39]. Titers were calculated as the reciprocal of the last $\mathrm{HI}$ positive serum dilution and samples with HI titers below $8\left(2^{3}\right)$ were considered negative.

\section{Results}

\section{Phylogenetic analysis}

The HA gene of $\mathrm{H} 5 \mathrm{~N} 1, \mathrm{H} 5 \mathrm{~N} 2$, and $\mathrm{H} 5 \mathrm{~N} 8$ viruses were grouped by subtypes and geographical regions (Figure 1). The H5N2 HPAI viruses that affected commercial turkey and layer farms in the Midwestern region in 2015 clustered together in the genetically distinct cluster "Midwest H5N2". Each gene of the isolates within the Midwest H5N2 cluster shared high sequence homology at nucleotide level (PB2: 99.6-100\%, PB1: 99.3-100\%, PA: 99.4100\%, HA: $99.3-100 \%$, NP: $99.4-100 \%$, NA: $99.5-100 \%$, M: $99.6-100 \%$, and NS: $99.4-100 \%)$. The phylogenetic analysis confirmed that the $\mathrm{Tk} / \mathrm{MN} / 15$ virus used in this study belongs to this Midwest H5N2 cluster.

\section{Infectivity and transmission}

The $\mathrm{BID}_{50}$ and $\mathrm{BLD}_{50}$ were determined for each of the three ages. Birds were considered infected if they had detectable virus along with clinical disease and mortality, or if they seroconverted by $14 \mathrm{dpc}$. For all age groups, none of the chickens inoculated with the low and medium doses died (Table 1). However, $100 \%$ of the chickens inoculated with the high dose of Tk/MN/15 virus became infected and died with a MDT of $4.8 \mathrm{dpc}$ for $5 \mathrm{w}$ broilers and $3.2 \mathrm{dpc}$ for both $8 \mathrm{w}$ broilers and $>30 \mathrm{w}$ breeders (Table 1); MDTs were not significantly different among group ages $(p>0.05)$. The surviving inoculated birds did not show evidence of clinical disease and they were all serologically negative based on $\mathrm{HI}$ data, thus all survivors were considered uninfected. The $\mathrm{BID}_{50}$ and the $\mathrm{BLD}_{50}$ for $\mathrm{Tk} / \mathrm{MN} / 15$ virus were the same in this study and resulted in $5.0 \log _{10} \mathrm{BLD}_{50}$ for all the age groups (Table 1).

Quantitation of viral shedding was performed by qRRT-PCR using extrapolation of a standard curve generated with the challenge virus via virus isolation and titration. Birds inoculated with the low and medium 


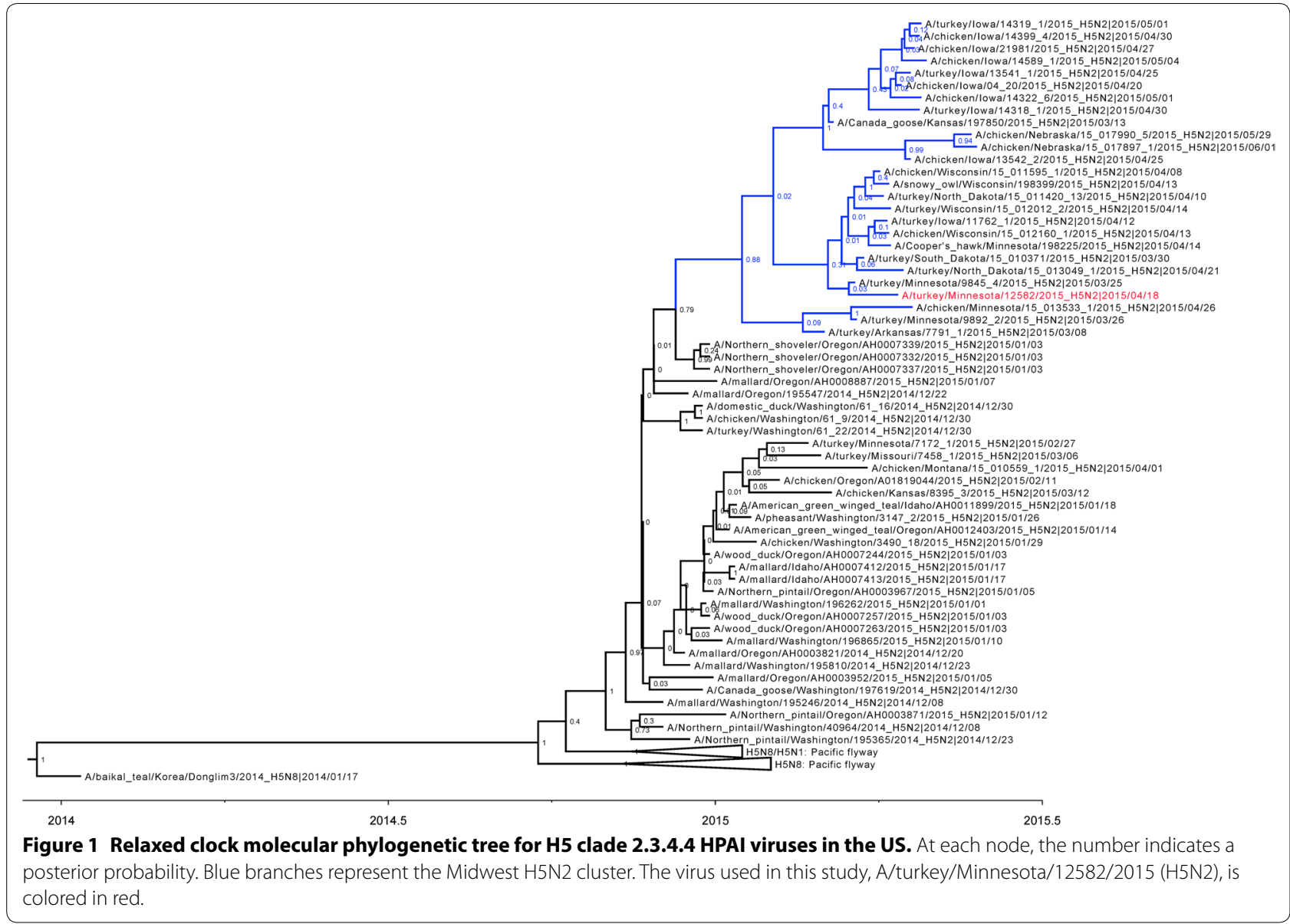

doses of $\mathrm{Tk} / \mathrm{MN} / 15$ virus did not shed detectable levels of virus (Figure 2). In contrast, birds in all three age groups inoculated with the high dose of $\mathrm{Tk} / \mathrm{MN} / 15$ virus shed high quantities of virus at 2 and $4 \mathrm{dpc}$ before dying (Figure 2). At $2 \mathrm{dpc}$, mean virus titers of 4.1, 5.1, and $5.9 \log _{10}$ $\mathrm{EID}_{50} / \mathrm{mL}$ were shed orally by $5 \mathrm{w}, 8 \mathrm{w}$ and $>30 \mathrm{w}$, respectively (Figure 2). Virus titers shed orally at $2 \mathrm{dpc}$ were statistically not different among the three age groups (Kruskal-Wallis test, $p>0.5$ ). At $4 \mathrm{dpc}$, mean virus titers of 4.0, 6.4, and $7.6 \log _{10} \mathrm{EID}_{50} / \mathrm{mL}$ were shed orally by $5 \mathrm{w}$, $8 \mathrm{w}$ and $>30 \mathrm{w}$, respectively (Figure 2). Statistical analysis could not be performed for $4 \mathrm{dpc}$ virus shedding due to the low number of birds alive for sampling.

The bird transmission studies were conducted by introducing three naïve birds of the same age into the isolators $24 \mathrm{~h}$ after the direct intranasal inoculation of five chickens of the corresponding age. Similar to what was observed for the inoculated birds, none of the contact chickens placed at the low and medium doses died (Table 1). However, $100 \%$ of the contact chickens placed at the high dose of $\mathrm{Tk} / \mathrm{MN} / 15$ virus became infected and died with a MDT of 5.3, 4.3, and 5.7 days post-exposure (dpe) for $5 \mathrm{w}, 8 \mathrm{w}$ and $>30 \mathrm{w}$, respectively (Table 1 ). Virus was not detected in the oral swabs of contact exposed birds placed at the low and medium challenge doses of any of the three age groups (Figure 2). This, together with the lack of clinical disease, mortality, or seroconversion (data not shown) indicates that surviving contact exposure birds from low and medium challenge doses did not become infected. In contrast, contact exposure birds placed at the high dose of all three age groups shed high quantities of virus at $4 \mathrm{dpc}(3 \mathrm{dpe}$ ) before dying, ranging from 5.4 to $6.2 \log _{10} \mathrm{EID}_{50} / \mathrm{mL}$; two of three $5 \mathrm{w}$-contact broilers were already shedding virus $\left(2.2\right.$ and $2.6 \log _{10}$ $\mathrm{EID}_{50} / \mathrm{mL}$ ) at $1 \mathrm{dpe}(2 \mathrm{dpc}$ in the figure) (Figure 2).

\section{Pathogenesis}

Two birds from each age group were challenged with the high dose of Tk/MN/15 virus to serve as a source of tissues. Mild illness was evident by $2 \mathrm{dpc}$ in all age groups, consisting of nonspecific clinical signs such as ruffled feathers, listlessness, and infraorbital swelling. Necropsies were performed at $3 \mathrm{dpc}$ on two dead birds per age group. Gross lesions were consistent in the three age 

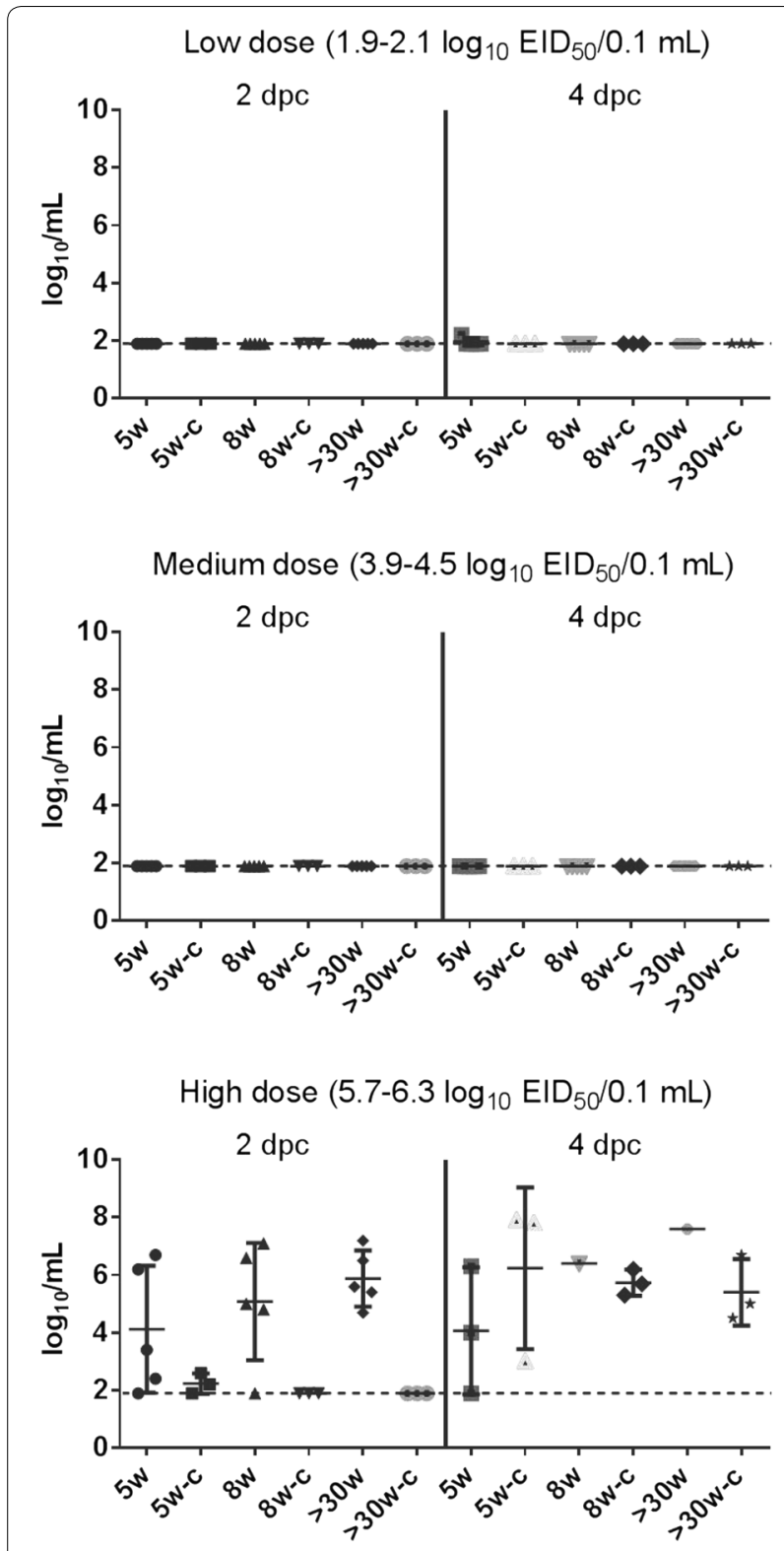

Figure 2 Mean viral oral shed from broilers directly inoculated or contact exposed with A/turkey/Minnesota/12582/2015 (H5N2) virus. Virus detection by qRRT-PCR at 2 and $4 \mathrm{dpc}$ (or 1 and $3 \mathrm{dpe}$ ). The limit of detection for TK/MN/15 virus was $2.0 \log _{10} \mathrm{EID}_{50} /$ $\mathrm{mL}$; therefore, qRRT-PCR negative samples were given a numeric value of $1.9 \log _{10} E \mathrm{EI}_{50} / \mathrm{mL}$. Intranasally inoculated 5 -week old broilers (5w), 8-week old broilers ( $8 w$ ), and $>30$-week-old broiler breeders (>30w); contact exposed 5-week old broilers (5w-c), 8-week old broilers $(8 w-c)$, and $>30$-week-old broiler breeders $(>30 w-c)$.

groups, and included multifocal necrosis in the pancreas sometimes accompanied by hemorrhagic duodenum, splenomegaly and renomegaly with parenchymal mottling, and petechial hemorrhages on the pericardial fat. The two necropsied $>30 \mathrm{w}$ breeders also had hemorrhagic tracheas. Similar type and severity of histological lesions, as well as viral antigen detection by immunohistochemistry, were observed for the three age groups (Figure 3). Multifocal necrosis with viral antigen was widespread in the parenchymal cells of most tissues, especially prominent in brain, heart, lung, spleen, pancreas, kidney, adrenal gland, and ovaries (in $>30 \mathrm{w}$ broiler breeders) (Table 2; Figure 3). Viral antigen staining was frequently observed in capillary endothelial cells of various tissues but not as widespread as observed with H5N1 Gs/GD lineage viruses [14, 37, 40].

Brain, spleen, heart, and lung were collected for viral RNA quantification by qRRT-PCR from two necropsied birds per age group challenged with the high dose of Tk/ $\mathrm{MN} / 15$ virus. Mean virus titers per tissue were calculated using the two birds from each age group necropsied at $3 \mathrm{dpc}$. High virus loads were detected in all the tissues and in all necropsied birds, ranging from $6.4 \log _{10}$ $\mathrm{EID}_{50} / \mathrm{g}$ of brain $(>30 \mathrm{w})$ to $9.2 \log _{10} \mathrm{EID}_{50} / \mathrm{g}$ of heart (5 and $>30 \mathrm{w}$ ) (Figure 4). Virus titers in each type of tissue were statistically not different among the three age groups (Kruskal-Wallis test, $p>0.7$ ).

\section{Discussion}

The H5N2 HPAI virus outbreaks in the Midwest during 2015 affected commercial turkey and layer chicken farms, but not broiler farms [5] despite close proximity of the three types of production systems [32]. To determine if broilers had any genetic resistance to HPAI virus infection and subsequent reduction in contact transmission, we investigated the ability of the Midwestern H5N2 clade 2.3.4.4 Tk/MN/15 virus to produce infection and be transmitted by direct contact among commercial slaughter-age broilers and adult broiler breeders under the stress of laying.

Previously, the experimental $\mathrm{BID}_{50}$ of $4.7 \log _{10} \mathrm{EID}_{50}$ was determined to be the upper cut-off for sufficient poultry adaptation for sustained transmission and spread of viruses between two or more premises in the field [41]. In the current infectivity and transmission studies, $100 \%$ of the birds inoculated with $6.0 \log _{10}$ EID $_{50}$ became infected and died which resulted in an estimated $\mathrm{BID}_{50}$ and $\mathrm{BLD}_{50}$ for Tk/MN/15 virus of $5.0 \log _{10} \mathrm{EID}_{50}$ in all age groups. This concurs with a previous study with 3 and $6 \mathrm{w}$ commercial broilers that experienced $100 \%$ mortality following inoculation with $6.5 \log _{10} \operatorname{EID}_{50}$ of this same virus (Dr Kapczynski, personal communication, 29 July 2016). In our study, the $\mathrm{BID}_{50}$ obtained is similar to the upper cut-off value, suggesting inadequate or sub-optimal adaption for sustained transmission in broilers. The MDT was statistically not different among the three age groups, being $4.8 \mathrm{dpc}$ for 5 -week-old broilers, and $3.2 \mathrm{dpc}$ for 8-week-old broilers and the $>30$-week-old broiler 

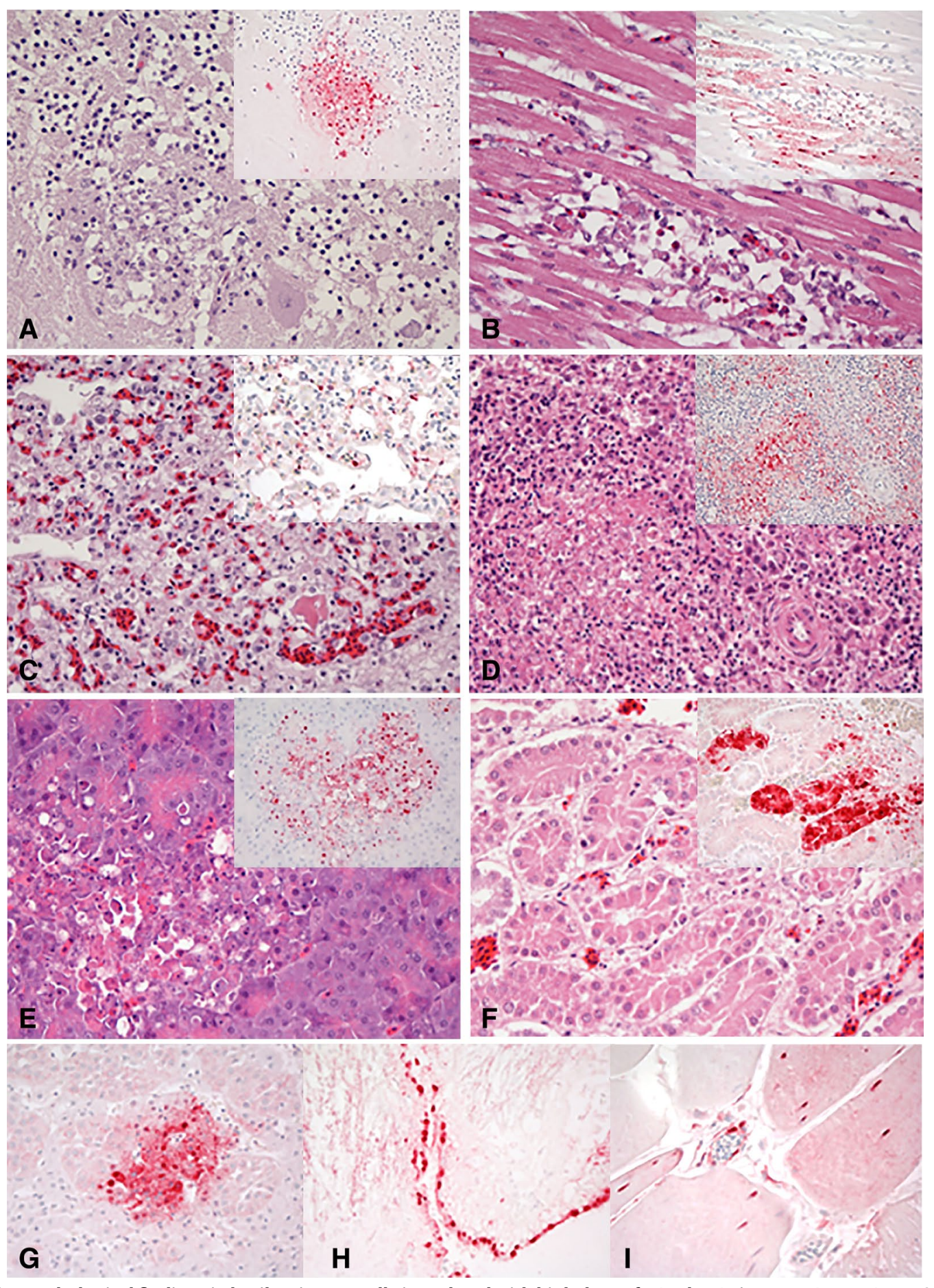

Figure 3 Histopathological findings in broilers intranasally inoculated with high dose of A/turkey/Minnesota/12582/2015 (H5N2)

virus. 5 -week old broilers ( $5 \mathrm{w}$ ), 8 -week old broilers $(8 \mathrm{w})$, $>30$-week-old broiler breeders $(>30 \mathrm{w}) ; \times 40$; immunohistochemical detection of viral antigen staining in red. A Cerebellum, $5 \mathrm{w}$. Vacuolation of the molecular and granular layers of the cerebellum with necrosis of the Purkinje neurons. Viral antigen present in the neuropil of both layers (inset). B Heart, 8w. Degeneration and necrosis of myocardiocytes. Extensive intranuclear and intracytoplasmic viral antigen of myocardiocytes (inset). C Lung, $5 \mathrm{w}$. Severe congestion, interstitial edema, and interstitial heterophilic and monocytic infiltration. Viral antigen in epithelium of air capillaries and vascular endothelium (inset). D Spleen, $5 \mathrm{w}$. Multifocal areas of necrosis and depletion of the white pulp. Viral antigen in mononuclear cells (inset). E Pancreas, $>30$ w. Multifocal areas of degeneration of pancreatic acinar cells. Viral antigen in acinar cells (inset). F Kidney, 8w. Focal necrosis of tubular epithelium. Extensive intranuclear and intracytoplasmic viral antigen of tubular epithelial cells (inset). G Adrenal gland, 8w. Diffuse intranuclear and cytoplasmatic viral antigen in corticotropic cells. H Brain, >30w. Viral antigen in ependymal cells of the ventricles. I Skeletal muscle, $8 \mathrm{~W}$. Intranuclear and intracytoplasmic viral antigen of myocytes and vascular endothelium. 
Table 2 Microscopic lesions and distribution of Al nucleoprotein antigen in tissues by immunohistochemistry

\begin{tabular}{|c|c|c|c|c|c|c|}
\hline \multirow[t]{2}{*}{ Tissue $^{a}$} & \multicolumn{3}{|c|}{ Commercial broiler } & \multirow{2}{*}{$\begin{array}{l}\text { SPF layer } \\
4 w^{b}\end{array}$} & \multirow[t]{2}{*}{ Viral antigen stained cell types } & \multirow[t]{2}{*}{ Type of lesion } \\
\hline & $5 w$ & $8 w$ & $>30 w$ & & & \\
\hline Trachea & + & + & - & ++ & Pseudostratified epithelial cells & $\begin{array}{l}\text { Focal necrosis with mild lymphoplasmacytic } \\
\text { inflammatory infiltrate }\end{array}$ \\
\hline Lung & +++ & +++ & + & +++ & $\begin{array}{l}\text { Epithelium of air capillaries, mononuclear cells, } \\
\text { endothelial cells }\end{array}$ & $\begin{array}{l}\text { Moderate congestion, necrosis, and monocyte } \\
\text { inflammatory infiltrate }\end{array}$ \\
\hline Duodenum & + & - & - & na & Macrophages & NSL \\
\hline Cecal tonsils & + & - & - & + & $\begin{array}{l}\text { Epithelial cells of villus, cells of the muscularis } \\
\text { externa, macrophages }\end{array}$ & $\begin{array}{l}\text { Focal necrosis with lymphoplasmacytic inflam- } \\
\text { matory infiltrate }\end{array}$ \\
\hline Pancreas & +++ & ++ & +++ & ++ & Acinar cells & $\begin{array}{l}\text { Mild degeneration of individual pancreatic } \\
\text { acinar cells }\end{array}$ \\
\hline Liver & + & + & + & + & Kupffer cells, hepatocytes, macrophages & $\begin{array}{l}\text { Focal necrosis with lymphoplasmacytic inflam- } \\
\text { matory infiltrate, perivascular cuffing }\end{array}$ \\
\hline Kidney & ++ & +++ & ++ & + & Tubular epithelial cells & $\begin{array}{l}\text { Focal necrosis of tubular epithelium with } \\
\text { lymphoplasmacytic inflammatory }\end{array}$ \\
\hline Adrenal gland & ++ & +++ & ++ & ++ & Corticotropic cells & $\begin{array}{l}\text { Multifocal areas of necrosis with mononuclear } \\
\text { inflammatory infiltrate }\end{array}$ \\
\hline Spleen & +++ & ++ & +++ & ++ & Mononuclear cells & $\begin{array}{l}\text { Multifocal areas of necrosis, hemorrhages, } \\
\text { depletion white pulp }\end{array}$ \\
\hline Thymus & + & + & + & ++ & Mononuclear cells & $\begin{array}{l}\text { Focal necrosis, mild lymphocyte depletion, } \\
\text { apoptotic lymphocytes }\end{array}$ \\
\hline Heart & +++ & +++ & +++ & +++ & Myocardiocytes & Multifocal necrosis of myocardiocytes \\
\hline Skeletal muscle & + & ++ & + & na & Myocytes, connective tissue, endothelial cells & NSL \\
\hline Brain & +++ & +++ & +++ & +++ & $\begin{array}{l}\text { Neurons, Purkinje cells, ependymal cells, glial } \\
\text { cells }\end{array}$ & $\begin{array}{l}\text { Malacia in cortex, necrosis of ependymal cells } \\
\text { of ventricles and epithelial cells of choroid } \\
\text { plexus, chromatolysis of Purkinje cells, lym- } \\
\text { phoplasmacytic infiltrate }\end{array}$ \\
\hline Ovaries & na & na & +++ & na & Tegument/interstitial tissue, granulocytes & $\begin{array}{l}\text { Focal necrosis with lymphoplasmacytic inflam- } \\
\text { matory infiltrate }\end{array}$ \\
\hline Infundibulum & na & na & + & na & Ciliated epithelial cells & NSL \\
\hline
\end{tabular}

4w: 4-week old SPF White Leghorn layers, 5w: 5-week old broilers, 8w: 8-week old broilers, na: not applicable, NSL: no significant lesions.

a Tissues not present appeared overtly normal on histopathological analysis and did not show positive immunohistochemical staining.

b For comparative purposes, data from DeJesus et al. [8] on 4-week old SPF White Leghorn chickens challenged with Tk/MN/15 virus have been added.

$-=$ no positive cells $;+=$ single positive cells $;++=$ scattered groups of positive cells; $+++=$ widespread positivity.

breeders. Collectively, the $\mathrm{BID}_{50}$ and $\mathrm{BLD}_{50}$ results suggest that differences in age are not a determining factor in the susceptibility of broilers for $\mathrm{Tk} / \mathrm{MN} / 15$ virus, and that this virus lacks optimal adaptation to broilers and/ or broilers are mildly genetically resistant to infection by this virus.

Virus shedding was in line with mortality results. Broilers of all ages inoculated with $6.0 \log _{10} \operatorname{EID}_{50}$ of $\mathrm{Tk} / \mathrm{MN} / 15$ virus shed high levels of virus prior to death resulting in transmission to contact exposed birds. The lack of significantly different amounts of virus shed further confirmed the absence of age-related differences in susceptibility. Broilers of all ages inoculated with the low and medium doses of $\mathrm{Tk} / \mathrm{MN} / 15$ virus did not become infected based on lack of mortality, virus shedding, and seroconversion. Collectively, our findings concur with Dejesus et al. [8] that observed virus shedding from SPF
White Leghorn chickens inoculated with a high dose of this same virus and transmission to contact birds. The overall virus shedding titers in broilers at all ages tested suggests a high potential of this virus to transmit within the broiler host population, yet high virus loads would be required to achieve the infectious dose upon initial exposure. However, field conditions with associated secondary infections or immunosuppression might lower such minimal exposure dose, thus emphasizing the importance of good biosecurity and management practices to explain the absence of affected broiler farms in 2015. The lack of age-related effects on susceptibility to $\mathrm{Tk} / \mathrm{MN} / 15$ virus was also supported by the pathogenesis data; broilers infected with the highest dose of virus showed histopathological findings that were similar among the three age groups, which were consistent with typical Gs/GD lineage H5N1 HPAI viruses $[14,37,40]$. When the three 


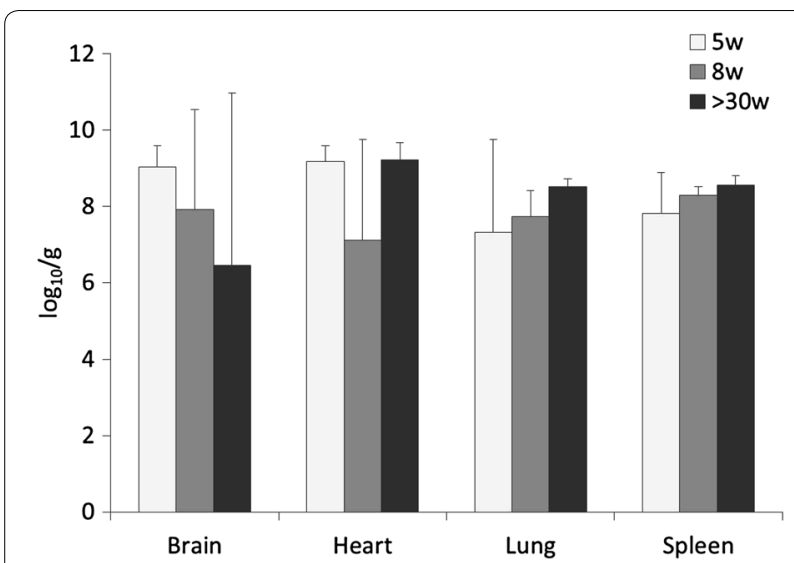

Figure 4 Virus detection in tissues of broilers inoculated with high dose of A/turkey/Minnesota/12582/2015 (H5N2) virus. Virus detection by qRRT-PCR. The limit of detection for TK/MN/15 virus was $3.0 \log _{10} \mathrm{EID}_{50} / \mathrm{g}$; therefore, qRRT-PCR negative samples were given a numeric value of $2.9 \log _{10} E_{1 D_{50}} / g$. Virus titers in each type of tissue were statistically similar among the three age groups (KruskalWallis test, $p>0.7)$. Intranasally inoculated 5 -week old broilers ( $5 \mathrm{w}$ ), 8-week old broilers (8w), >30-week-old broiler breeders (>30w).

ages of broilers were compared using systemic replication tested by qRRT-PCR, levels of virus found in each tissue were not significantly different.

Recently, 4-week-old turkeys experimentally challenged with $\mathrm{Tk} / \mathrm{MN} / 15$ virus had the same $\mathrm{BID}_{50}$ and $\mathrm{BLD}_{50}$ of $5.0 \log _{10} \mathrm{EID}_{50}$ as broilers, but a longer MDT of $5.9 \mathrm{dpc}$ [9]. In contrast, a recent study by DeJesus et al. [8] using the same $\mathrm{Tk} / \mathrm{MN} / 15$ virus had a $\mathrm{BID}_{50}$ and $\mathrm{BLD}_{50}$ of $3.6 \log _{10} \mathrm{EID}_{50}$ and MDT of $2.0 \mathrm{dpc}$ in 4-weekold specific pathogen free (SPF) White Leghorn chickens. All the studies combined suggest that the broiler breed is less susceptible to Midwestern H5N2 poultry viruses than the layer breed, but similarly susceptible as turkeys. Interestingly, 80 and $90 \%$ of the layer and turkey farms, respectively, affected during the Midwestern outbreaks were premises with birds over 9 weeks old, and no premises with birds younger than 4 weeks old were affected [42]. These data suggest a potential age-related susceptibility factor in layer hens and turkeys that calls for further experimental confirmation. In any case, a mild genetic resistance to infection might explain only partially why broiler premises were not affected during the 2015 outbreak. The type of production system could have played a greater role than initially expected; the potential chance of virus introduction into broiler premises is likely much lower than in layer premises because broilers are shorterlived birds and, therefore, faster bird turnover rate occurs with fewer times for workers, equipment, and supplies to enter the premises. This hypothesis might also explain the lack of infected layer chicken and turkey premises holding <4-week-old birds during the 2015 outbreak. In addition, better biosecurity practices on broiler farms than in layer and turkey farms, many of which are directly dependent on the production system, may have prevented exposure on many broiler farms, likely contributing to the absence of outbreaks on broiler premises. While there were broilers at different stages of production within the control and surveillance zones, based upon permits it appeared that some broiler producers did not restock (Dr Mia Torchetti, personal communication). Similarly, in 1996-1998 an H7N2 LPAI virus in Pennsylvania affected layer flocks but not broiler flocks, despite close proximity of infected premises [26, 43]. Also, in the 2014 H5N2 clade 2.3.4.4 HPAI outbreak in British Columbia, Canada, all commercial poultry farms with the exception of chicken broiler farms were affected [44].

In conclusion, the present study indicates that age is not a determining factor in susceptibility of broilers to $\mathrm{H} 5 \mathrm{~N} 2$ clade 2.3.4.4 HPAI virus. The epidemiology of infected premises of the H5N2 outbreak in the Midwest in 2015 also appears consistent with the data presented in this study. Based on $\mathrm{BLD}_{50}$, the $\mathrm{Tk} / \mathrm{MN} / 15$ virus is slightly less adapted to broilers than to layers, which may partly explain why layer chickens and not broiler chickens were affected during the outbreak. However, the high pathogenicity of the virus and the readiness of replication and transmission in broilers exposed to high doses of Tk/ $\mathrm{MN} / 15$ virus indicate that good biosecurity practices and disease control measures likely contributed to the prevention of HPAI virus being introduced and spread in broiler premises.

\section{Abbreviations \\ 5w: 5-week-old broilers; 8w: 8-week-old broilers; >30w: >30-week-old broiler breeders; Al: avian influenza; Gs/GD: A/goose/Guangdong/1/1996; H5N2 Tk/ MN/15: A/turkey/Minnesota/12582/2015; BHI: brain heart infusion; 5W-c: con- tact 5-week old broilers; $8 \mathrm{w}$-c: contact 8 -week old broilers; $>30 \mathrm{w}$-c: contact $>30$-week-old broiler breeders; dpc: day post-challenge; dpe: days post-expo- sure; ECE: embryonating chicken eggs; HA: hemagglutinin; HI: hemagglutinin inhibition; HPAl: high pathogenicity avian influenza; LPAl: Iow pathogenic avian influenza; $\mathrm{MHC}$ : major histocompatibility complex; $\mathrm{BID}_{50}$ : mean bird infectious dose; $\mathrm{BLD}_{50}$ : mean bird lethal dose; MDT: mean death time; $\mathrm{EID}_{50}$ : mean egg infectious dose; na: not applicable; NSL: no significant lesions; qRRT- PCR: quantitative real-time RT-PCR; SPF: specific pathogen free.}

\section{Competing interests}

The authors declare that they have no competing interests.

\section{Authors' contributions}

DES, MJPJ, and ES conceived this project. KB, DHL, and CB conducted animal experiments and sample processing. $\mathrm{KB}$ analyzed the data. $\mathrm{DHL}$ genetically characterized the challenge virus. $\mathrm{KB}, \mathrm{DHL}, \mathrm{CB}, \mathrm{MJPJ}, \mathrm{ES}$, and DES wrote and reviewed the manuscript. All authors read and approved the final manuscript.

\section{Acknowledgements}

The authors would like to thank Dr John Smith and Fieldale Farms Corp. for kindly providing the birds utilized in this experiment. The authors gratefully acknowledge Roger Brock, Keith Crawford, and Gerald Damron for their excellent technical assistance. 


\section{Ethics approval}

All procedures were performed according to the requirements of protocols approved by the Institutional Animal Care and Use Committee, and Institutional Biosecurity Committee.

\section{Funding}

This work was funded by USDA CRIS Project 6040-32000-063-00D. Its contents are solely the responsibility of the authors and do not necessarily represent the official views of the USDA. Mention of trade names or commercial products in this publication is solely for the purpose of providing specific information and does not imply recommendation or endorsement by the USDA.

\section{Received: 19 September 2016 Accepted: 2 November 2016} Published online: 21 November 2016

\section{References}

1. Lee DH, Torchetti MK, Winker K, Ip HS, Song CS, Swayne DE (2015) Intercontinental spread of Asian-origin H5N8 to North America through Beringia by migratory birds. J Virol 89:6521-6524

2. Ip HS, Torchetti MK, Crespo R, Kohrs P, DeBruyn P, Mansfield KG, Baszler T, Badcoe L, Bodenstein B, Shearn-Bochsler V, Killian ML, Pedersen JC, Hines N, Gidlewski T, DeLiberto T, Sleeman JM (2015) Novel Eurasian highly pathogenic avian influenza A H5 viruses in wild birds, Washington, USA, 2014. Emerg Infect Dis 21:886-890

3. Torchetti MK, Killian ML, Dusek RJ, Pedersen JC, Hines N, Bodenstein B, White CL, Ip HS (2015) Novel H5 clade 2.3.4.4 reassortant (H5N1) virus from a green-winged teal in Washington, USA. Genome Announc 3:e00195-e00215

4. Lee DH, Bahl J, Torchetti MK, Killian ML, Ip HS, DeLiberto TJ, Swayne DE (2016) Highly pathogenic avian influenza viruses and generation of novel reassortants, United States, 2014-2015. Emerg Infect Dis 22:1283-1285

5. United States Department of Agriculture, Animal and Plant Health Inspection Service (2015) Highly pathogenic avian influenza infected premises 2014-2015. https://www.aphis.usda.gov/animal_health/animal_dis_spec/poultry/downloads/hpai-positive-premises-2014-2015.pdf. Accessed 9 Nov 2016

6. Swayne DE, Hill RE, Clifford J (2016) Safe application of regionalization for trade in poultry and poultry products during highly pathogenic avian influenza outbreaks in the USA. Avian Pathol 7:1-16

7. Jhung MA, Nelson DI, Centers for Disease Control and Prevention (CDC) (2015) Outbreaks of avian influenza A (H5N2), (H5N8), and (H5N1) among birds-United States, December 2014-January 2015. MMWR Morb Mortal Wkly Rep 64:111

8. DeJesus E, Costa-Hurtado M, Smith D, Lee DH, Spackman E, Kapczynski DR, Torchetti MK, Killian ML, Suarez DL, Swayne DE, Pantin-Jackwood MJ (2016) Changes in adaptation of H5N2 highly pathogenic avian influenza H5 clade 2.3.4.4 viruses in chickens and mallards. Virology 499:52-64

9. Spackman E, Pantin-Jackwood MJ, Kapczynski DR, Swayne DE, Suarez DL: H5N2 highly pathogenic avian influenza viruses from the US 2014-2015 outbreak have an unusually long pre-clinical period in turkeys. BMC Vet Res (in press)

10. Bertran K, Swayne DE, Pantin-Jackwood MJ, Kapczynski DR, Spackman E, Suarez DL (2016) Lack of chicken adaptation of newly emergent Eurasian H5N8 and reassortant H5N2 high pathogenicity avian influenza viruses in the US is consistent with restricted poultry outbreaks in the Pacific flyway during 2014-2015. Virology 494:190-197

11. Pantin-Jackwood MJ, Costa-Hurtado M, Shepherd E, DeJesus E, Smith D, Spackman E, Kapczynski DR, Suarez DL, Stallknecht DE, Swayne DE (2016) Pathogenicity and transmission of $\mathrm{H} 5$ and $\mathrm{H} 7$ highly pathogenic avian influenza viruses in mallards. J Virol 90:9967-9982

12. Pantin-Jackwood MJ, Swayne DE (2009) Pathogenesis and pathobiology of avian influenza virus infection in birds. Rev Sci Tech 28:113-136

13. Swayne DE, Pantin-Jackwood M (2006) Pathogenicity of avian influenza viruses in poultry. Dev Biol 124:61-67

14. Spickler AR, Trampel DW, Roth JA (2008) The onset of virus shedding and clinical signs in chickens infected with high-pathogenicity and lowpathogenicity avian influenza viruses. Avian Pathol 37:555-577
15. Swayne DE, Halvorson DA (2008) Influenza. In: Saif YM, Glisson JR, Fadly AM, McDougald LR, Nolan LK (eds) Diseases of poultry. Blackwell Publishing, Ames

16. Capua I, Marangon S, Selli L, Alexander DJ, Swayne DE, Pozza MD, Parenti E, Cancellotti FM (1999) Outbreaks of highly pathogenic avian influenza (H5N2) in Italy during October 1997 to January 1998. Avian Pathol 28:455-460

17. Capua I, Mutinelli F, Terregino C, Cattoli G, Manvell RJ, Burlini F (2000) Highly pathogenic avian influenza (H7N1) in ostriches farmed in Italy. Vet Rec 146:356

18. Kwon YK, Joh SJ, Kim MC, Sung HW, Lee YJ, Choi JG, Lee EK, Kim JH (2005) Highly pathogenic avian influenza (H5N1) in the commercial domestic ducks of South Korea. Avian Pathol 34:367-370

19. Pantin-Jackwood MJ, Suarez DL, Spackman E, Swayne DE (2007) Age at infection affects the pathogenicity of Asian highly pathogenic avian influenza H5N1 viruses in ducks. Virus Res 130:151-161

20. Lavoie ET, Sorrell EM, Perez DR, Ottinger MA (2007) Immunosenescence and age-related susceptibility to influenza virus in Japanese quail. Dev Comp Immunol 31:407-414

21. Koenen ME, Boonstra-Blom AG, Jeurissen SH (2002) Immunological differences between layer- and broiler-type chickens. Vet Immunol Immunopathol 89:47-56

22. Zheng Q, Zhang Y, Chen Y, Yang N, Wang XJ, Zhu D (2009) Systematic identification of genes involved in divergent skeletal muscle growth rates of broiler and layer chickens. BMC Genomics 10:87

23. Druyan S (2010) The effects of genetic line (broilers vs. layers) on embryo development. Poult Sci 89:1457-1467

24. Swayne DE, Radin MJ, Hoepf TM, Slemons RD (1994) Acute renal failure as the cause of death in chickens following intravenous inoculation with avian influenza virus A/chicken/Alabama/7395/75 (H4N8). Avian Dis 38:151-157

25. Ko JH, Jin HK, Asano A, Takada A, Ninomiya A, Kida H, Hokiyama H, Ohara M, Tsuzuki M, Nishibori M, Mizutani M, Watanabe T (2002) Polymorphisms and the differential antiviral activity of the chicken Mx gene. Genome Res 12:595-601

26. Henzler DJ, Kradel DC, Davison S, Ziegler AF, Singletary D, DeBok P, Castro AE, Lu H, Eckroade R, Swayne D, Lagoda W, Schmucker B, Nesselrodt A (2003) Epidemiology, production losses, and control measures associated with an outbreak of avian influenza subtype H7N2 in Pennsylvania (1996-98). Avian Dis 47:1022-1036

27. Kalaya B, Sawat T, Neramit S, Voravit V, Voravit S, Tadayoshi M (2006) Influence of MHC class II haplotypes on avian influenza traits in Thai indigenous chicken. J Poult Sci 43:120-125

28. Balkissoon D, Staines K, McCauley J, Wood J, Young J, Kaufman J, Butter C (2007) Low frequency of the Mx allele for viral resistance predates recent intensive selection in domestic chickens. Immunogenetics 59:687-691

29. Sironi L, Williams JL, Moreno-Martin AM, Ramelli P, Stella A, Jianlin H, Weigend S, Lombardi G, Cordioli P, Mariani P (2008) Susceptibility of different chicken lines to H7N1 highly pathogenic avian influenza virus and the role of Mx gene polymorphism coding amino acid position 631. Virology 380:152-156

30. Hunt HD, Jadhao S, Swayne DE (2010) Major histocompatibility complex and background genes in chickens influence susceptibility to high pathogenicity avian influenza virus. Avian Dis 54:572-575

31. Matsuu A, Kobayashi T, Patchimasiri T, Shiina T, Suzuki S, Chaichoune K, Ratanakorn P, Hiromoto Y, Abe H, Parchariyanon S, Saito T (2016) Pathogenicity of genetically similar, H5N1 highly pathogenic avian influenza virus strains in chicken and the differences in sensitivity among different chicken breeds. PLoS One 11:e0153649

32. Census of Agriculture, United States Department of Agriculture, Animal and Plant Health Inspection Service (2012) 2012 census Ag atlas maps_livestock and animals. https://www.agcensus.usda.gov/Publications/2012/Online_Resources/Ag_Atlas_Maps/Livestock_and_Animals/. Accessed 9 Nov 2016

33. Swayne DE, Senne DA, Beard CW (1998) Influenza. In: Swayne DE, Glisson JR, Jackwood MW, Pearson JE, Reed WM (eds) Isolation and identification of avian pathogens. American Association of Avian Pathologists, Kennett Square

34. Edgar RC (2004) MUSCLE: multiple sequence alignment with high accuracy and high throughput. Nucleic Acids Res 32:1792-1797 
35. Drummond AJ, Rambaut A (2007) BEAST: Bayesian evolutionary analysis by sampling trees. BMC Evol Biol 7:214

36. Spackman E, Senne DA, Myers TJ, Bulaga LL, Garber LP, Perdue ML, Lohman K, Daum LT, Suarez DL (2002) Development of a real-time reverse transcriptase PCR assay for type A influenza virus and the avian $\mathrm{H} 5$ and H7 hemagglutinin subtypes. J Clin Microbiol 40:3256-3260

37. Perkins LE, Swayne DE (2001) Pathobiology of A/chicken/Hong Kong/220/97 (H5N1) avian influenza virus in seven gallinaceous species. Vet Pathol 38:149-164

38. Abbas MA, Spackman E, Fouchier R, Smith D, Ahmed Z, Siddique N, Sarmento L, Naeem K, McKinley ET, Hameed A, Rehmani S, Swayne DE (2011) H7 avian influenza virus vaccines protect chickens against challenge with antigenically diverse isolates. Vaccine 29:7424-7429

39. Pedersen JC (2008) Hemagglutination-inhibition test for avian influenza virus subtype identification and the detection and quantitation of serum antibodies to the avian influenza virus. Methods Mol Biol 436:53-66

40. Swayne DE (2000) Understanding the ecology and epidemiology of avian influenza viruses: implications for zoonotic potential. In: Brown CC, Bolin CA (eds) Emerging diseases of animals. ASM Press, Washington, D.C
41. Swayne DE, Slemons RD (2008) Using mean infectious dose of high- and low-pathogenicity avian influenza viruses originating from wild duck and poultry as one measure of infectivity and adaptation to poultry. Avian Dis 52:455-460

42. United States Department of Agriculture, Animal and Plant Health Inspection Service (2015) Epidemiologic and other analyses of HPAIaffected poultry flocks-September 2015. https://www.aphis.usda.gov/ animal_health/animal_dis_spec/poultry/downloads/EpidemiologicAnalysis-Sept-2015.pdf. Accessed 9 Nov 2016

43. Ziegler AF, Davison S, Acland H, Eckroade RJ (1999) Characteristics of H7N2 (nonpathogenic) avian influenza virus infections in commercial layers, in Pennsylvania, 1997-98. Avian Dis 43:142-149

44. Xu W, Berhane Y, Dube C, Liang B, Pasick J, VanDomselaar G, Alexandersen $S$ (2016) Epidemiological and evolutionary inference of the transmission network of the 2014 highly pathogenic avian influenza H5N2 outbreak in British Columbia, Canada. Sci Rep 6:30858

\section{Submit your next manuscript to BioMed Central and we will help you at every step:}

- We accept pre-submission inquiries

- Our selector tool helps you to find the most relevant journal

- We provide round the clock customer support

- Convenient online submission

- Thorough peer review

- Inclusion in PubMed and all major indexing services

- Maximum visibility for your research

Submit your manuscript at www.biomedcentral.com/submit 